\title{
Effects of Beta-Hydroxy-Beta-Methylbutyrate in Partially Hepatectomized Rats
}

\author{
M. HOLEČEK ${ }^{1}$, M. VODENIČAROVOVÁ ${ }^{1}$ \\ ${ }^{1}$ Department of Physiology, Charles University, Faculty of Medicine in Hradec Králové, Czech \\ Republic
}

Received January 17, 2018

Accepted March 16, 2018

On-line July 25, 2018

\begin{abstract}
Summary
Beta-hydroxy-beta-methylbutyrate (HMB) is a leucine metabolite with protein anabolic effects. Since HMB is synthesized in the liver, unique effects of exogenous HMB intake may be hypothesized in subjects with liver disease, in which muscle wasting is frequently found. We studied effects of HMB on the liver and soleus (SOL) and extensor digitorum longus (EDL) muscles in partially-hepatectomized $(\mathrm{PH})$ rats. HMB or saline was infused using osmotic pumps to $\mathrm{PH}$ or sham-operated rats for 7 days. We found lower body weight and protein content in EDL of $\mathrm{PH}$ rats treated with saline than in sham-operated animals. These effects were insignificant in HMB treated animals. In blood plasma of $\mathrm{PH}$ rats treated with $\mathrm{HMB}$ we found lower concentrations of creatinine and higher concentrations of urea and branched-chain amino acids (BCAA; valine, leucine, and isoleucine) than in $\mathrm{PH}$ animals treated with saline. HMB increased BCAA concentrations in SOL and EDL of $\mathrm{PH}$ animals and decreased proteolysis in EDL of both sham-operated and $\mathrm{PH}$ animals. In the livers of $\mathrm{PH}$ rats treated with $\mathrm{HMB}$ we found higher DNA content, DNA fragmentation, and BCAA concentrations than in saline-treated animals. The results indicate that HMB affects metabolism of BCAA and has positive influence on protein balance in muscles. Further studies are needed to clarify the effect of HMB on liver regeneration.
\end{abstract}

\section{Key words}

Branched-chain amino acids $\bullet$ Supplements $\bullet$ Liver regeneration • Muscle wasting

\section{Corresponding author}

M. Holeček, Department of Physiology, Charles University, Faculty of Medicine in Hradec Králové, Šimkova 870, 50003
Hradec Králové, Czech Republic. Fax: +420-49-5210190. E-mail: holecek@lfhk.cuni.cz

\section{Introduction}

Beta-hydroxy-beta-methylbutyrate (HMB) is a leucine metabolite with protein anabolic effects mediated mostly by changes in proteolysis. HMB decreases proteasome expression and proteasome enzyme activities, attenuates the upregulation of caspases, and reduces the apoptosis of myonuclei (Smith et al. 2005, Kovarik et al. 2010, Eley et al. 2008, Hao et al. 2011). Studies performed under in vitro conditions and various animal models suggest that HMB may be effective in the treatment of sarcopenia in the elderly and muscle wasting in various forms of cachexia (Holecek 2017). In human studies, positive results were observed in chronic pulmonary disease, hip fracture, AIDS- and cancerrelated cachexia, and in well-trained athletes (Clark et al. 2000, Olveira et al. 2016, Rathmacher et al. 2004, Ekinci et al. 2016, Durkalec-Michalski and Jeszka 2016, Portal et al. 2011, Durkalec-Michalski et al. 2017).

Since HMB is synthesized in the liver, unique effects of exogenous HMB may be hypothesized in subjects with liver disease, in which muscle wasting is frequently found (Dasarathy and Hatzoglou 2018). There are, however, no reports regarding the effects of HMB supplementation in subjects with liver injury. HMB administration may have a positive influence not only on protein balance in muscles, but also on repair of damaged membranous structures through its role as a precursor of cholesterol (Nissen and Abumrad 1997). In 
addition, because HMB is synthesized from leucine, its administration may affect metabolism of all three branched-chain amino acids (BCAA; valine, leucine, and isoleucine), which share the same metabolic pathways (Fig. 1). The BCAA have a regulatory role in protein synthesis (Kimball and Jefferson 2001) and ammonia detoxification to glutamine in muscles (Holecek et al. 2011) and, therefore, alterations in their metabolism may affect protein balance and the course of hepatic disease (Holecek 2010).

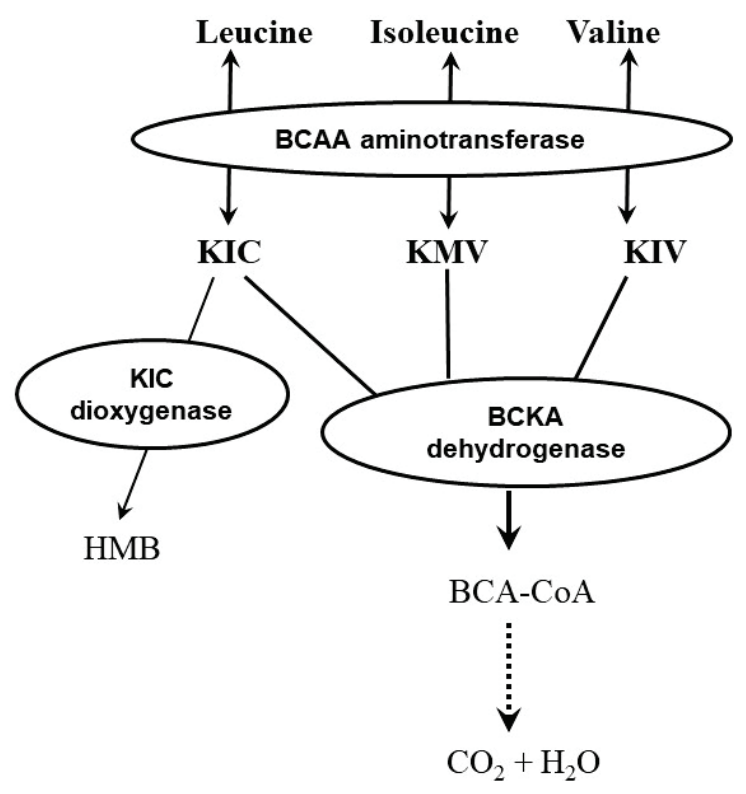

Fig. 1. Pathways of HMB synthesis and BCAA metabolism.

The aim of the present study was to examine the effects of HMB supplementation in rats after partial (68\%) hepatectomy (PH). We studied the effects on blood biochemical markers, BCAA levels in blood and tissues, and protein balance in muscles (Fig. 2). In addition, we attempted to assess how HMB affects liver regeneration, which has a crucial role in maintaining homeostatic function of the liver in the case of hepatic injury. We evaluated changes in DNA and protein content, expression of proliferating cell nuclear antigen (PCNA), and DNA fragmentation level. The effects on protein metabolism were examined by alterations in protein content and the activities of the ubiquitinproteasome system, the major proteolytic system in muscles. Because there are a good number of papers showing the different sensitivities of slow- and fasttwitch muscles to various signals (Kadlcikova et al. 2004, Holecek and Micuda 2017), we examined muscles of different metabolic properties, i.e. musculus soleus (SOL, slow-twitch, red muscle) and musculus extensor digitorum longus (EDL, fast-twitch, white muscle).

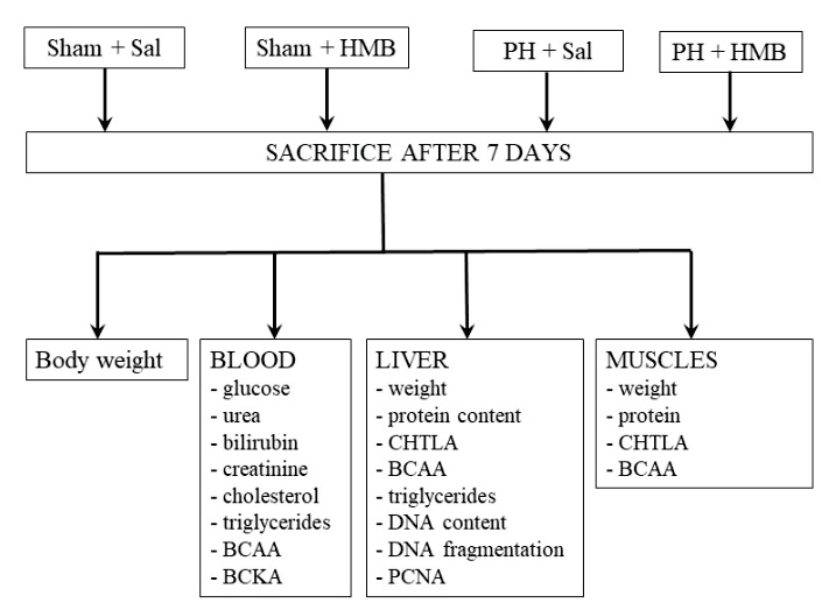

Fig. 2. Design of the study and examinations performed to estimate the effects of HMB in healthy and PH animals.

\section{Methods}

\section{Animals and materials}

Male Wistar rats (Charles River, Sulzfeld, Germany) weighing approximately $300 \mathrm{~g}$ were housed in standardized cages in quarters with controlled temperature and a 12-hour light-dark cycle. Rats were maintained on an ST-1 (Velaz, CR) standard laboratory diet containing (w/w) $24 \%$ nitrogenous compounds, $4 \%$ fat, $70 \%$ carbohydrates and $2 \%$ minerals and vitamins, and were provided drinking water ad libitum. The Animal Care and Use Committee of Charles University, Faculty of Medicine in Hradec Kralove approved this study. Animals were treated carefully by animal experts educated and trained in how to manipulate animals to maintain a healthy environment and to reduce distress and minimize potential pain and suffering.

HMB (calcium salt) was purchased from Santa Cruz Biotechnology (Dallas, TX, USA) and osmotic pumps were purchased from Alzet Osmotic Pumps (Cupertion, CA, USA). Saline (solution of $0.9 \% \mathrm{w} / \mathrm{v}$ of $\mathrm{NaCl}$ ) was from B. Braun (Melsungen, Germany). Dimethyl sulfoxide, 7-amino-4-methylcoumarin, Z-PheArg 7-amido-4-methylcoumarin hydrochloride, Z-PhePhe-fluoromethyl ketone, N-succinyl-Leu-Leu-Val-Tyr7-amido-4-methylcoumarin, DL-dithiothreitol, Trizma base, Folin \& Ciocalteu's phenol reagent, deoxyribonucleic acid, free glycerol reagent, and magnesium chloride were obtained from Sigma-Aldrich (St. Louis, MO, USA). AccQ•Fluor ${ }^{\mathrm{TM}}$ Reagent Kit was 
from Waters (Milford, MA, USA), sodium acetate from Merck (Darmstadt, Germany), sulphuric acid from Lachema (Neratovice, Czech Republic), MG-132 from Biomol (Hamburg, Germany).

\section{Study design (Fig. 2)}

Partial hepatectomy $(\mathrm{PH}, 68 \%$ of liver tissue was removed) was conducted in diethyl ether narcosis according to Higgins and Anderson (1931). A midline abdominal incision was made to perform a sham operation. Rats were randomly divided into 4 groups, each containing 10 animals: (1) control, sham-operated animals treated with saline (Sham + Sal); (2) shamoperated animals treated with HMB (Sham + HMB); (3) $\mathrm{PH}$ animals treated with saline $(\mathrm{PH}+\mathrm{Sal})$; and (4) $\mathrm{PH}$ animals treated with $\mathrm{HMB}(\mathrm{PH}+\mathrm{HMB})$. HMB (200 mg/kg/day) or saline was administered using osmotic pumps placed subcutaneously between the shoulders for 7 days. Animals recovered within $1 \mathrm{~h}$ after surgery and then were freely moving. The dose of HMB was based on results of our previous studies in which the decrease in proteasome enzyme activities was observed in muscles (Holecek et al. 2009).

At the end of the study, the animals were sacrificed after overnight starvation in ether anaesthesia by exsanguination from abdominal aorta. The liver, SOL and EDL were quickly removed and weighed, then small pieces (approximately $0.1 \mathrm{~g}$ ) of the tissues were frozen in liquid nitrogen. Blood was collected in heparinized tubes and immediately centrifuged for $15 \mathrm{~min}$ at 2,200 $\mathrm{xg}$ using a refrigerated centrifuge, blood plasma was transferred into a clean polypropylene tubes using a Pasteur pipette.

\section{Blood biochemical markers}

Plasma levels of glucose, urea, creatinine, bilirubin, triglycerides and cholesterol were measured using commercial tests (Boehringer, Mannheim, Germany; Elitech, Sées, France and Lachema, Brno, Czech Republic). The homogeneous assays (direct methods) have been used for low-density lipoproteincholesterol (LDL cholesterol) and high-density lipoprotein-cholesterol (HDL cholesterol) determination (Roche Diagnostics GmbH, Mannheim, Germany).

\section{Liver and muscle biochemistry}

The DNA content in the liver was determined using the diphenylamine reaction (Burton 1956). Protein contents in the liver and muscles were measured according to Lowry et al. (1951). Triglycerides were determined by ethanolic $\mathrm{KOH}$ saponification followed by assay for glycerol (Sigma Chemical, St. Louis, MO, USA). The results were expressed per weight of wet tissue and per $\mathrm{kg}$ of body weight.

\section{$B C A A$ and branched-chain keto acids (BCKA)}

Concentrations of BCAA and BCKA were determined in supernatants of deproteinized samples of blood plasma and tissues by high-performance liquid chromatography (Aliance 2695, Waters, Milford, MA, USA) as described previously (Holecek et al. 2017). Amino acid concentrations were measured after derivatization with 6-aminoquinolyl-N-hydroxysuccinimidyl carbamate using norleucine as an internal standard. $o$-phenylenediamine derivatization was used for determination of BCKA. The quinoxalinol derivatives of BCKA were detected using fluorescence with emission and excitation at $410 \mathrm{~nm}$ and $350 \mathrm{~nm}$, respectively. The results were expressed per liter of blood plasma or gram of wet tissue.

\section{Chymotrypsin-like activity (CHTLA) of proteasome}

The CHTLA of the proteasome in the liver and muscles was determined using the fluorogenic substrate Suc-LLVY-MCA (Gomes-Marcondes and Tisdale 2002), as previously described in detail (Holecek and Kovarik 2011). The fluorescence of the samples was measured at an excitation wavelength of $340 \mathrm{~nm}$ and an emission wavelength of $440 \mathrm{~nm}$ (Tecan Infinite M200). A standard curve was established for 7-amino-4-methylcoumarin (AMC), which allowed expression of the enzyme activities in nmol of $\mathrm{AMC} / \mathrm{g}$ protein $/ \mathrm{h}$.

\section{Proliferating cell nuclear antigen (PCNA)}

PCNA is a nuclear protein, which serves as a cofactor for DNA polymerase and is often used as a marker for cell proliferation. Briefly, liver samples were homogenized in 3 volumes of lysis buffer and centrifuged at $9,000 \mathrm{xg}$ at $4{ }^{\circ} \mathrm{C}$ for $15 \mathrm{~min}$. Quantification of PCNA in the supernatant was performed in microplates using the respective anti-PCNA antibodies (CytoSelect ${ }^{\mathrm{TM}}$ PCNA ELISA kit, Cell Biolabs, Inc., San Diego, CA, USA). Absorbance was measured at $450 \mathrm{~nm}$ (Tecan Infinite M200). Each PCNA unknown sample, standard and blank were assayed in duplicate. The results were expressed in ng of PCNA per mg of the supernatant protein concentration. 


\section{DNA fragmentation}

Degradation of nuclear DNA into nucleosomal units (a hallmark of apoptotic cell death) was estimated using the Cell Detection ELISA Kit (Roche Diagnostic, Pleasanton, CA, USA). Briefly, samples of hepatic tissue (approximately $100 \mathrm{mg}$ ) were homogenized in lysis buffer and were centrifuged at $13,000 \mathrm{xg}$ for $15 \mathrm{~min}$. The supernatant was incubated for $2 \mathrm{~h}$ at room temperature with an antihistone-biotin/anti-DNA-PD reagent in a streptavidin-coated microplate. Wells were washed three times, and $100 \mu \mathrm{l}$ of substrate solution (ABTS) was added to each well. Absorbance was measured at 405 and $490 \mathrm{~nm}$ (Tecan Infinite M200). Each sample, standard and blank were assayed in duplicate. Absorbance was normalized to the protein concentration of the supernatant, and the results were expressed as arbitrary units per $\mathrm{mg}$ of protein.

\section{Statistical analysis}

The results are expressed as the means \pm SE. Analysis of variance followed by a Bonferroni multiple comparisons procedure were used to detect differences with a significance level of $\mathrm{P}<0.05$. The statistical software NCSS 2001 (Kaysville, UT, USA) was used for the analyses.

\section{Results}

\section{Alterations in body weights (Table 1) and food intake}

There were no differences among weights of animals in specific experimental groups at the beginning of the study. On the last day of the experiment, body weights of $\mathrm{PH}$ animals treated with saline were lower than sham-operated animals. The weights of $\mathrm{PH}$ animals treated with HMB did not differ from other groups. Food intake was lower in $\mathrm{PH}$ animals during the first 2 days after surgery $(\sim 60 \%$ and $90 \%$ of sham-operated animals).
Blood biochemistry (Table 2)

Infusion of HMB increased concentrations of glucose and HDL and decreased atherogenicity index in sham-operated rats. Higher concentrations of creatinine and bilirubin and lower concentrations of glucose, triglycerides and urea, and decreased atherogenicity index were observed in $\mathrm{PH}$ animals treated by saline than in sham operated controls. In PH rats treated with HMB we found higher atherogenicity index and higher concentrations of urea and triglycerides and lower concentrations of glucose and creatinine than in $\mathrm{PH}$ rats treated with saline.

\section{BCAA and BCKA in blood plasma (Table 3)}

PH animals treated with saline showed increased concentrations of KIV, but the effect on BCAA levels was insignificant. HMB infusion increased concentrations of all three BCAA and BCKA in PH animals and increased the concentration of KIC in sham-operated animals.

\section{BCAA concentrations in tissues (Table 4)}

PH did not affect BCAA concentrations in the liver and muscles. However, in all tissues of $\mathrm{PH}$ animals treated with HMB there were higher concentrations of all three BCAA when compared to $\mathrm{PH}$ animals treated with saline. Except for valine (in SOL and EDL) and leucine (in SOL), the values were higher compared to those of the corresponding group of sham-operated animals.

\section{Alterations in the muscles (Table 5)}

The effects of $\mathrm{PH}$ and $\mathrm{HMB}$ on muscle weight and protein content were mostly insignificant. Lower content of proteins was found in the EDL of PH rats treated with saline when compared with sham-operated controls. In HMB-treated animals, the effect of PH was insignificant. HMB treatment decreased CHTLA in the EDL of both sham-operated and PH animals.

Table 1. Effects of HMB and PH on gain/loss of body weight.

\begin{tabular}{lcccc}
\hline Body weight & $\begin{array}{c}\text { Sham }+ \text { Sal } \\
(\mathbf{n}=\mathbf{9})\end{array}$ & $\begin{array}{c}\text { Sham }+ \text { HMB } \\
(\mathbf{n = 1 0})\end{array}$ & $\begin{array}{c}\text { PH + Sal } \\
(\mathbf{n = 1 0})\end{array}$ & $\begin{array}{c}\text { PH + HMB } \\
(\mathbf{n}=\mathbf{9})\end{array}$ \\
\hline- start & $293 \pm 5$ & $305 \pm 10$ & $300 \pm 7$ & $297 \pm 5$ \\
- end & $326 \pm 6$ & $316 \pm 8$ & $298 \pm 9^{\#}$ & $309 \pm 7$ \\
- gain/loss & $34 \pm 4$ & $11 \pm 9$ & $-2 \pm 3^{\#}$ & $12 \pm 4$ \\
\hline
\end{tabular}

Means $\pm \mathrm{SE}$, ANOVA and Bonferroni multiple comparisons. ${ }^{*} \mathrm{P}<0.05$, effect of $\mathrm{PH}$ (compared to the corresponding sham-operated group). PH, partial hepatectomy; Sal, saline; Sham, sham surgery; HMB, $\beta$-hydroxy- $\beta$-methylbutyrate. 
Table 2. Effects of HMB and PH on blood biochemistry.

\begin{tabular}{lcccc}
\hline Variable & $\begin{array}{c}\text { Sham + Sal } \\
(\mathbf{n = 9})\end{array}$ & $\begin{array}{c}\text { Sham + HMB } \\
(\mathbf{n = 1 0})\end{array}$ & $\begin{array}{c}\text { PH + Sal } \\
(\mathbf{n = 1 0})\end{array}$ & $\begin{array}{c}\text { PH + HMB } \\
(\mathbf{n = 9})\end{array}$ \\
\hline Glucose $(\mathrm{mmol} / \mathrm{l})$ & $8.96 \pm 0.36$ & $10.23 \pm 0.33^{*}$ & $8.51 \pm 0.21^{\#}$ & $6.06 \pm 0.28^{* \#}$ \\
Urea $(\mathrm{mmol} / \mathrm{l})$ & $4.99 \pm 0.19$ & $4.47 \pm 0.20$ & $3.77 \pm 0.21^{\#}$ & $4.97 \pm 0.36^{*}$ \\
Creatinine $(\mu \mathrm{mol} / \mathrm{l})$ & $18.67 \pm 0.53$ & $20.00 \pm 0.54$ & $26.10 \pm 0.97^{\#}$ & $22.50 \pm 0.45^{* \#}$ \\
Bilirubin $(\mathrm{mmol} / \mathrm{l})$ & $0.52 \pm 0.19$ & $0.50 \pm 0.22$ & $3.00 \pm 0.00^{\#}$ & $3.10 \pm 0.10^{\#}$ \\
Triglycerides $(\mathrm{mmol} / \mathrm{l})$ & $1.13 \pm 0.05$ & $1.19 \pm 0.05$ & $0.62 \pm 0.05^{\#}$ & $1.08 \pm 0.10^{*}$ \\
Cholesterol $(\mathrm{mmol} / \mathrm{l})$ & $1.63 \pm 0.08$ & $1.91 \pm 0.08$ & $1.50 \pm 0.07$ & $1.65 \pm 0.08$ \\
HDL cholesterol $(\mathrm{mmol} / \mathrm{l})$ & $1.05 \pm 0.05$ & $1.45 \pm 0.06^{*}$ & $1.24 \pm 0.08$ & $1.02 \pm 0.10^{\#}$ \\
LDL cholesterol $(\mathrm{mmol} / \mathrm{l})$ & $0.42 \pm 0.03$ & $0.39 \pm 0.03$ & $0.37 \pm 0.02$ & $0.44 \pm 0.02$ \\
Atherogenicity index & $0.56 \pm 0.02$ & $0.33 \pm 0.02^{*}$ & $0.24 \pm 0.04^{\#}$ & $0.72 \pm 0.12^{* \#}$ \\
\hline
\end{tabular}

Means $\pm \mathrm{SE}$, ANOVA and Bonferroni multiple comparisons. $* \mathrm{P}<0.05$, effect of $\mathrm{HMB}$ (compared to the corresponding saline-treated group); ${ }^{\#} \mathrm{P}<0.05$, effect of $\mathrm{PH}$ (compared to the corresponding sham-operated group). PH, partial hepatectomy; Sal, saline; Sham, sham surgery; HMB, $\beta$-hydroxy- $\beta$-methylbutyrate. Atherogenicity index was calculated as: (cholesterol - HDL cholesterol)/HDL cholesterol.

Table 3. Effects of HMB and PH on BCAA and BCKA concentrations in blood plasma ( $\mu \mathrm{mol} / \mathrm{l})$.

\begin{tabular}{|c|c|c|c|c|}
\hline Variable & $\begin{array}{c}\text { Sham }+ \text { Sal } \\
(n=9)\end{array}$ & $\begin{array}{c}\text { Sham + HMB } \\
(n=10)\end{array}$ & $\begin{array}{c}\text { PH + Sal } \\
(n=10)\end{array}$ & $\begin{array}{c}\mathbf{P H}+\mathbf{H M B} \\
(\mathbf{n}=9)\end{array}$ \\
\hline \multicolumn{5}{|l|}{$B C A A$} \\
\hline Valine & $149 \pm 3$ & $146 \pm 5$ & $137 \pm 5$ & $171 \pm 11 *$ \\
\hline Leucine & $125 \pm 2$ & $124 \pm 4$ & $116 \pm 5$ & $144 \pm 9^{*}$ \\
\hline Isoleucine & $72 \pm 2$ & $71 \pm 2$ & $69 \pm 3$ & $88 \pm 6^{* \#}$ \\
\hline$\Sigma B C A A$ & $346 \pm 6$ & $342 \pm 10$ & $322 \pm 12$ & $403 \pm 27^{* \#}$ \\
\hline \multicolumn{5}{|l|}{$B C K A$} \\
\hline$\alpha$-ketoisovalerate & $4.3 \pm 0.2$ & $5.4 \pm 0.3$ & $5.8 \pm 0.5^{\#}$ & $9.2 \pm 0.5^{* \#}$ \\
\hline$\alpha$-ketoisocaproate & $9.9 \pm 0.7$ & $13.5 \pm 0.9^{*}$ & $15.2 \pm 1.8$ & $25.7 \pm 2.0$ *\# \\
\hline$\alpha$-keto- $\beta$-methylvalerate & $9.9 \pm 0.4$ & $8.9 \pm 0.4$ & $8.9 \pm 0.7$ & $13.4 \pm 0.9^{* \#}$ \\
\hline$\Sigma B C K A$ & $24.0 \pm 1.1$ & $27.8 \pm 1.6$ & $30.0 \pm 2.9$ & $48.2 \pm 3.4 *^{*}$ \\
\hline
\end{tabular}

Means \pm SE for 10 animals per group, ANOVA and Bonferroni multiple comparisons. $* P<0.05$, effect of HMB (compared to the corresponding saline-treated group); ${ }^{\#} \mathrm{P}<0.05$, effect of $\mathrm{PH}$ (compared to the corresponding sham-operated group). $\mathrm{PH}$, partial hepatectomy; Sal, saline; Sham, sham surgery; HMB, $\beta$-hydroxy- $\beta$-methylbutyrate.

\section{Alterations in the liver}

Lower weight and the content of DNA and protein in the liver of $\mathrm{PH}$ animals indicate that liver regeneration was not yet complete. The content of liver DNA, but not the weight and protein contents, was higher in $\mathrm{PH}$ rats treated with $\mathrm{HMB}$ than in $\mathrm{PH}$ animals treated with saline. We did not find differences in triglyceride contents among the groups. HMB treatment decreased values of CHTLA in both sham-operated and $\mathrm{PH}$ animals (Table 6).

Expression of PCNA (a hallmark of DNA synthesis) was higher in the liver of $\mathrm{PH}$ animals. Differences between saline- and HMB-treated animals were not observed (Fig. 3).
DNA fragmentation (a hallmark of apoptosis) in the regenerating remnant of the liver tissue was higher in $\mathrm{PH}$ animals than in sham-operated controls. Higher values were found in animals treated with HMB (Fig. 4).

\section{Discussion}

To the best of our knowledge, this is the first study assessing the effects of HMB in animals with impaired liver function. The results clearly demonstrate that HMB exerts significant effects on BCAA and cholesterol metabolism, protein metabolism in muscles, and liver regeneration in subjects with liver resection. 
Table 4. Effects of HMB and PH on BCAA concentrations in tissues ( $\mathrm{nmol} / \mathrm{g})$.

\begin{tabular}{|c|c|c|c|c|}
\hline & $\begin{array}{c}\text { Sham + Sal } \\
\quad(n=9)\end{array}$ & $\begin{array}{c}\text { Sham + HMB } \\
(\mathrm{n}=10)\end{array}$ & $\begin{array}{c}\mathbf{P H}+\text { Sal } \\
(\mathrm{n}=10)\end{array}$ & $\begin{array}{c}\mathbf{P H}+\mathbf{H M B} \\
(\mathbf{n}=9)\end{array}$ \\
\hline \multicolumn{5}{|l|}{ LIVER } \\
\hline Valine & $216 \pm 11$ & $246 \pm 7$ & $247 \pm 9$ & $298 \pm 17^{* \#}$ \\
\hline Leucine & $231 \pm 11$ & $250 \pm 6$ & $263 \pm 10$ & $317 \pm 17^{* \#}$ \\
\hline Isoleucine & $123 \pm 7$ & $137 \pm 4$ & $145 \pm 5$ & $175 \pm 10^{* \#}$ \\
\hline$B C A A$ & $570 \pm 29$ & $632 \pm 17$ & $655 \pm 23$ & $790 \pm 43^{* \#}$ \\
\hline \multicolumn{5}{|l|}{ SOL } \\
\hline Valine & $134 \pm 5$ & $134 \pm 6$ & $124 \pm 6$ & $148 \pm 8^{*}$ \\
\hline Leucine & $135 \pm 13$ & $119 \pm 4$ & $111 \pm 7$ & $165 \pm 27^{*}$ \\
\hline Isoleucine & $64 \pm 2$ & $64 \pm 3$ & $63 \pm 4$ & $79 \pm 5^{* \#}$ \\
\hline$B C A A$ & $333 \pm 14$ & $318 \pm 12$ & $298 \pm 16$ & $375 \pm 32 *$ \\
\hline \multicolumn{5}{|l|}{$E D L$} \\
\hline Valine & $145 \pm 6$ & $145 \pm 6$ & $130 \pm 6$ & $168 \pm 9^{*}$ \\
\hline Leucine & $110 \pm 5$ & $107 \pm 5$ & $107 \pm 6$ & $140 \pm 8^{* \#}$ \\
\hline Isoleucine & $68 \pm 3$ & $66 \pm 3$ & $65 \pm 4$ & $88 \pm 6^{* \#}$ \\
\hline$B C A A$ & $323 \pm 13$ & $318 \pm 12$ & $302 \pm 15$ & $395 \pm 23^{* \#}$ \\
\hline
\end{tabular}

Means $\pm \mathrm{SE}$, ANOVA and Bonferroni multiple comparisons. $* \mathrm{P}<0.05$, effect of $\mathrm{HMB}$ (compared to the corresponding saline-treated group); ${ }^{*} \mathrm{P}<0.05$, effect of $\mathrm{PH}$ (compared to the corresponding sham-operated group). PH, partial hepatectomy; Sal, saline; Sham, sham surgery; HMB, $\beta$-hydroxy- $\beta$-methylbutyrate. EDL, musculus extensor digitorum longus; $S O L$, musculus soleus.

Table 5. Effects of HMB and PH on muscles.

\begin{tabular}{|c|c|c|c|c|}
\hline & $\begin{array}{c}\text { Sham }+ \text { Sal } \\
(n=9)\end{array}$ & $\begin{array}{c}\text { Sham }+ \text { HMB } \\
(n=10)\end{array}$ & $\begin{array}{c}\text { PH + Sal } \\
(n=10)\end{array}$ & $\begin{array}{c}\text { PH + HMB } \\
(n=9)\end{array}$ \\
\hline \multicolumn{5}{|l|}{ SOL } \\
\hline weight $-m g$ & $172 \pm 7$ & $163 \pm 6$ & $156 \pm 6$ & $161 \pm 4$ \\
\hline$-g / k g$ b.w. & $0.53 \pm 0.02$ & $0.52 \pm 0.01$ & $0.52 \pm 0.01$ & $0.52 \pm 0.01$ \\
\hline protein $-m g$ & $23 \pm 1$ & $23 \pm 1$ & $21 \pm 1$ & $22 \pm 1$ \\
\hline$-m g / k g$ b.w. & $72 \pm 2$ & $73 \pm 3$ & $71 \pm 2$ & $71 \pm 4$ \\
\hline CHTLA $(\mathrm{nmol} A M C / m g / h)$ & $0.81 \pm 0.04$ & $0.83 \pm 0.04$ & $0.97 \pm 0.07$ & $0.98 \pm 0.06$ \\
\hline \multicolumn{5}{|l|}{$E D L$} \\
\hline weight $-m g$ & $144 \pm 3$ & $143 \pm 4$ & $132 \pm 2$ & $143 \pm 3$ \\
\hline$-g / k g b . w$ & $0.45 \pm 0.01$ & $0.45 \pm 0.01$ & $0.45 \pm 0.01$ & $0.46 \pm 0.01$ \\
\hline protein $-m g$ & $27 \pm 2$ & $26 \pm 2$ & $21 \pm 1^{\#}$ & $25 \pm 1^{*}$ \\
\hline$-m g / k g$ b.w. & $82 \pm 3$ & $80 \pm 6$ & $70 \pm 3^{\#}$ & $80 \pm 2$ \\
\hline CHTLA $(\mathrm{nmol} A M C / \mathrm{mg} / \mathrm{h})$ & $1.30 \pm 0.06$ & $0.94 \pm 0.05^{*}$ & $1.05 \pm 0.05^{\#}$ & $0.83 \pm 0.07 *$ \\
\hline
\end{tabular}

Means $\pm \mathrm{SE}, \mathrm{ANOVA}$ and Bonferroni multiple comparisons. $* \mathrm{P}<0.05$, effect of $\mathrm{HMB}$ (compared to the corresponding saline-treated group); ${ }^{*} \mathrm{P}<0.05$, effect of $\mathrm{PH}$ (compared to the corresponding sham-operated group). $\mathrm{PH}$, partial hepatectomy; Sal, saline; Sham, sham surgery; HMB, $\beta$-hydroxy- $\beta$-methylbutyrate; CHTLA, chymotrypsin-like activity. 
Table 6. Effects of HMB and PH on the liver.

\begin{tabular}{|c|c|c|c|c|}
\hline & $\begin{array}{c}\text { Sham }+ \text { Sal } \\
(n=9)\end{array}$ & $\begin{array}{c}\text { Sham + HMB } \\
(n=10)\end{array}$ & $\begin{array}{c}\text { PH + Sal } \\
(n=10)\end{array}$ & $\begin{array}{c}\mathbf{P H}+\mathbf{H M B} \\
(\mathbf{n}=\mathbf{9})\end{array}$ \\
\hline \multicolumn{5}{|l|}{ Wet weight } \\
\hline$-g$ & $11.13 \pm 0.23$ & $10.92 \pm 0.29$ & $8.12 \pm 0.33^{\#}$ & $8.09 \pm 0.33^{\#}$ \\
\hline$-g / k g b . w$. & $34.13 \pm 0.57$ & $34.57 \pm 0.42$ & $27.25 \pm 0.81^{\#}$ & $26.13 \pm 0.58^{\#}$ \\
\hline \multicolumn{5}{|l|}{ Dry weight } \\
\hline$-g$ & $3.34 \pm 0.06$ & $3.37 \pm 0.08$ & $2.33 \pm 0.09^{\#}$ & $2.26 \pm 0.10^{\#}$ \\
\hline$-g / k g b . w$ & $10.26 \pm 0.17$ & $10.68 \pm 0.13$ & $7.81 \pm 0.23^{\#}$ & $7.30 \pm 0.19^{\#}$ \\
\hline - \% of wet weight & $30.06 \pm 0.11$ & $30.90 \pm 0.17 *$ & $28.66 \pm 0.14^{\#}$ & $27.93 \pm 0.20^{* \#}$ \\
\hline \multicolumn{5}{|l|}{$D N A$} \\
\hline$-m g$ & $31.45 \pm 0.95$ & $31.00 \pm 1.48$ & $19.93 \pm 1.19^{\#}$ & $25.50 \pm 1.36^{* \#}$ \\
\hline$-m g / k g b . w$ & $96.48 \pm 2.64$ & $98.76 \pm 5.50$ & $67.07 \pm 3.83^{\#}$ & $82.92 \pm 4.76^{* \#}$ \\
\hline \multicolumn{5}{|l|}{ Protein } \\
\hline$-g$ & $2.16 \pm 0.08$ & $2.28 \pm 0.09$ & $1.43 \pm 0.07^{\#}$ & $1.43 \pm 0.07$ \\
\hline$-g / k g b . w$ & $6.64 \pm 0.25$ & $7.23 \pm 0.23$ & $4.81 \pm 0.20^{\#}$ & $4.62 \pm 0.16^{\#}$ \\
\hline \multicolumn{5}{|l|}{ Triglycerides } \\
\hline$-m g$ & $167 \pm 12$ & $175 \pm 13$ & $131 \pm 5$ & $149 \pm 11$ \\
\hline$-m g / k g ~ b . w$. & $514 \pm 39$ & $549 \pm 30$ & $439 \pm 13$ & $481 \pm 27$ \\
\hline CHTLA (nmol AMC/mg/h) & $3.84 \pm 0.21$ & $2.99 \pm 0.13^{*}$ & $4.83 \pm 0.14^{\#}$ & $4.07 \pm 0.12^{\#}$ \\
\hline
\end{tabular}

Means $\pm \mathrm{SE}$, ANOVA and Bonferroni multiple comparisons. $* \mathrm{P}<0.05$, effect of $\mathrm{HMB}$ (compared to the corresponding saline-treated group); ${ }^{*} \mathrm{P}<0.05$, effect of $\mathrm{PH}$ (compared to the corresponding sham-operated group). $\mathrm{PH}$, partial hepatectomy; Sal, saline; Sham, sham surgery; HMB, $\beta$-hydroxy- $\beta$-methylbutyrate; CHTLA, chymotrypsin-like activity.

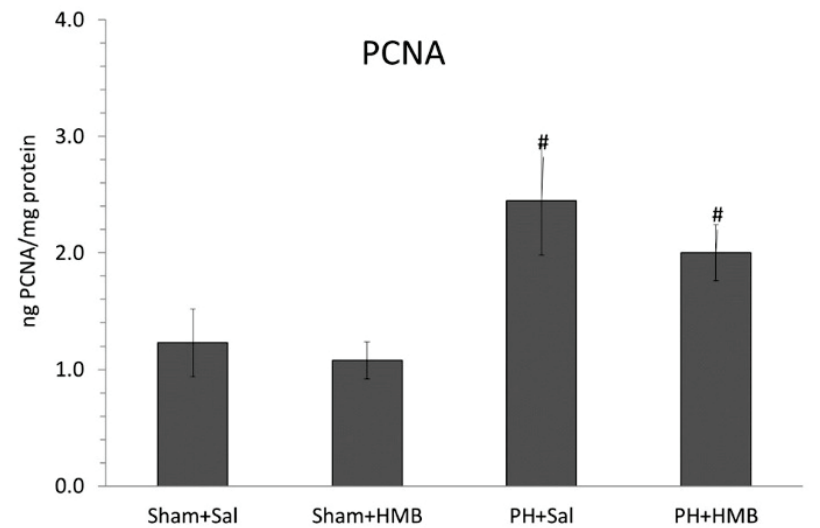

Fig. 3. Effect of $\mathrm{HMB}$ and $\mathrm{PH}$ on proliferating cell nuclear antigen (PCNA) expression. Means \pm SE for 9-10 animals per group, ANOVA and Bonferroni multiple comparisons. $* P<0.05$, effect of HMB (compared to the corresponding saline-treated group); ${ }^{\#} \mathrm{P}<0.05$, effect of $\mathrm{PH}$ (compared to the corresponding shamoperated group). $\mathrm{PH}$, partial hepatectomy; Sal, saline; Sham, sham surgery; HMB, $\beta$-hydroxy- $\beta$-methylbutyrate.

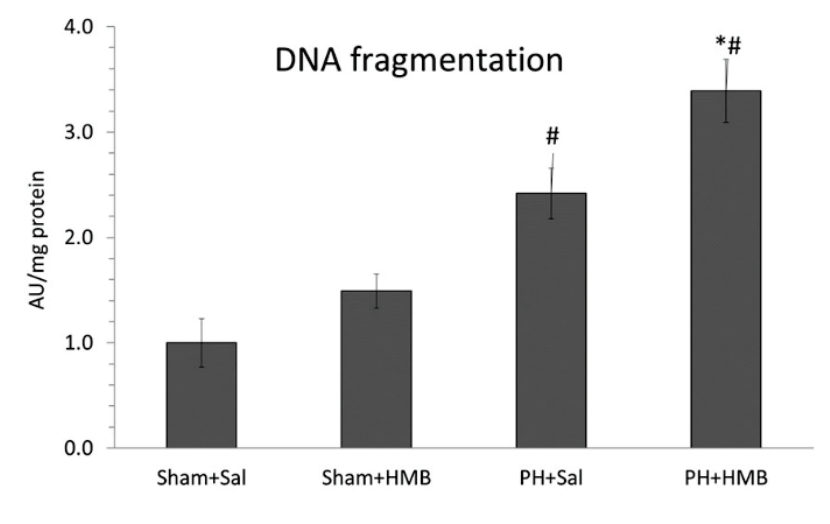

Fig. 4. Effect of $H M B$ and $P H$ on DNA fragmentation. Means $\pm S E$ for 9-10 animals per group, ANOVA and Bonferroni multiple comparisons. $* \mathrm{P}<0.05$, effect of $\mathrm{HMB}$ (compared to the corresponding saline-treated group); ${ }^{\#} \mathrm{P}<0.05$, effect of $\mathrm{PH}$ (compared to the corresponding sham-operated group). $\mathrm{PH}$, partial hepatectomy; Sal, saline; Sham, sham surgery; HMB, $\beta$-hydroxy- $\beta$-methylbutyrate. 
Effects on body and muscle weights and on protein metabolism in muscle

Lower body weights of $\mathrm{PH}$ animals treated by saline when compared to sham-operated animals, and no decrease in body weight of $\mathrm{PH}$ animals treated with $\mathrm{HMB}$, indicate positive effects of HMB on the nutritional status of PH animals. We have not observed differences in food intake between $\mathrm{PH}$ animals administered HMB and saline, therefore, the effect of HMB is not related to its possible influence on appetite. Unfortunately, detailed examination of the mass and composition of individual tissues, which may explain origin of the difference, is not available. Nevertheless, the decrease in protein content in the EDL of PH animals treated by saline, which was not found in the HMB-treated group, and significantly lower CHTLA in the EDL of PH animals treated with HMB than in the saline-treated animals, indicate the positive effects of HMB on skeletal muscle, particularly on muscles with a high content of white fibres.

Insignificant effects of HMB on body weight, and the weight and protein content of the muscles of sham-operated animals, is in line with the opinion that stress signals are needed for expression of anabolic effects of exogenous HMB (Holecek 2017, DurkalecMichalski et al. 2017).

\section{Alterations in blood biochemical markers}

The increase of HDL cholesterol and the decrease of atherogenicity index in sham-operated animals treated with HMB might be of clinical importance. This finding is in line with our previous study, in which the animals were infused with HMB for one day (Holecek et al. 2009), but not in line with studies in humans, which showed that oral administration of HMB decreases levels of total and LDL cholesterol (Nissen et al. 2000). As it is recognized that high levels of HDL cholesterol may prevent cardiovascular disease, our findings do not restrain the idea that $\mathrm{HMB}$ has positive effects on profile of blood lipids. However, investigations of the effects of HMB on cholesterol metabolism are warranted to make a conclusion.

The causes of lower levels of urea and triglycerides, and higher levels of bilirubin, in PH animals treated with saline than in sham-operated animals, are decreased abilities of the reduced mass of hepatic tissue to detoxify ammonia to urea, to form and release lipoproteins, and to remove bilirubin from the blood, respectively. Therefore, higher concentrations of urea and triglycerides in the blood of PH animals treated with HMB, when compared with animals treated with saline, can be regarded as a sign of positive effects of HMB on the liver.

Increased concentrations of creatinine in $\mathrm{PH}$ rats indicate that $\mathrm{PH}$ may decrease the glomerular filtration rate. Considering our observations of positive effects of HMB on body weight and protein balance in muscles, lower values of creatinine should indicate some benefits of HMB on kidney function of $\mathrm{PH}$ animals. Unfortunately, there are no data regarding specific effects of HMB on the kidneys.

\section{Alterations in $B C A A$ and $B C K A$ concentrations}

Increased concentration of KIC in the blood plasma of sham-operated controls treated with HMB suggests that HMB supplementation affects leucine metabolism. This might be due to attenuated utilization of endogenous KIC produced in a dioxygenase reaction, or due to decreased activity of the BCKA dehydrogenase, which is the rate limiting enzyme in BCAA catabolism.

Explanation of enhanced concentrations of the BCAA in the blood, liver, and muscles of PH animals treated with $\mathrm{HMB}$ can be based on a recent finding that HMB impairs insulin sensitivity (Yonamine et al. 2014). There are a number of reports of increased concentrations of BCAA in various insulin-resistance or insulin-deficient states such as diabetes and starvation (Wang et al. 2011, Holecek et al. 2001, Holecek and Micuda 2017). Impairment of insulin sensitivity in individuals treated with HMB may be more pronounced, if insulin resistance already exists, as occurs after PH. In our study, a role may have also reduced mass of hepatic tissue, in which high amounts of the BCAA and BCKA are used for protein synthesis or oxidized. Because it is believed that low concentrations of the BCAA play a role in the pathogenesis of hepatic encephalopathy and muscle wasting (Holecek 2010), the effect of HMB on BCAA levels might have some benefits for subjects with liver disease.

\section{Alterations in the liver}

The remarkable effect of HMB treatment on the liver of PH animals was a higher content of DNA when compared with saline-treated animals. Surprisingly, we did not find corresponding differences in liver weight, protein content, and PCNA expression. Higher values of DNA fragmentation in the liver of $\mathrm{PH}$ animals are in line with the theory that there is a balance between hepatocyte 
proliferation and apoptosis during liver regeneration, and that enhanced apoptosis is essential for eliminating unwanted DNA-damaged cells (Zhou et al. 2015). Therefore, higher values of DNA fragmentation in HMB-treated animals may indicate a stimulatory effect of HMB on DNA synthesis in the early period of liver regeneration.

As the main task of the study was to examine the effects of chronical intake of HMB on various metabolic parameters of the blood plasma, muscles, and the liver, we did not examine the rates of DNA synthesis and mitotic activity of hepatocytes at the initial phase of liver regeneration. Therefore, we cannot make a conclusion about the origin of increased DNA content.

Decreased CHTLA in both $\mathrm{PH}$ and shamoperated animals treated with HMB indicates that HMB exerts inhibitory effect on ubiquitin-proteasome system not only in muscles, but also in the liver.

\section{Conclusions}

The results indicate that $\mathrm{HMB}$ administration affects metabolism of the BCAA and has a positive influence on plasma lipids and on protein balance in muscles. Further studies are needed to clarify the effect of exogenous HMB on liver regeneration, effects of various doses and forms of HMB, and effects of HMB in other types of liver injury. Of particular therapeutic significance could be effects of HMB in subjects with liver cirrhosis, in which muscle wasting is a common complication that adversely affects clinical outcomes.

\section{Conflict of Interest}

There is no conflict of interest.

\section{Acknowledgements}

This study was supported by the program PROGRES Q40/02. The authors wish to thank R. Fingrova, K. Sildbergerova, and D. Jezkova for their technical assistance.

\section{Abbreviations}

AMC, 7-amino-4-methylcoumarin; BCAA, branchedchain amino acids (valine, leucine, and isoleucine); BCKA, branched-chain keto acids; CHTLA, chymotrypsin-like activity; EDL, musculus extensor digitorum longus; HMB, $\beta$-hydroxy- $\beta$-methylbutyrate; KIC, $\quad \alpha$-ketoisocaproate (ketoleucine); KIV, $\alpha$-ketoisovalerate (ketovaline); KMV, $\alpha$-keto- $\beta$ methylvalerate (ketoisoleucine]; PCNA, proliferating cell nuclear antigen; $\mathrm{PH}$, partial hepatectomy; Sal, saline solution; Sham, sham surgery; SOL, musculus soleus.

\section{References}

BURTON K: A study of the conditions and mechanism of the diphenylamine reaction for the colorimetric estimation of deoxyribonucleic acid. Biochem J 62: 315-323, 1956.

CLARK RH, FELEKE G, DIN M, YASMIN T, SINGH G, KHAN FA, RATHMACHER JA: Nutritional treatment for acquired immunodeficiency virus-associated wasting using beta-hydroxy beta-methylbutyrate, glutamine, and arginine: a randomized, double-blind, placebo-controlled study. JPEN J Parenter Enteral Nutr 24: 133-139, 2000.

DASARATHY S, HATZOGLOU M: Hyperammonemia and proteostasis in cirrhosis. Curr Opin Clin Nutr Metab Care 21: $30-36,2018$.

DURKALEC-MICHALSKI K, JESZKA J: The effect of $\beta$-hydroxy- $\beta$-methylbutyrate on aerobic capacity and body composition in trained athletes. Strength Cond Res 30: 2617-2626, 2016.

DURKALEC-MICHALSKI K, JESZKA J, PODGÓRSKI T: The effect of a 12-week beta-hydroxy-beta-methylbutyrate (HMB) supplementation on highly-trained combat sports athletes: a randomised, double-blind, placebocontrolled crossover study. Nutrients 9: 753, 2017.

EKINCI O, YANIK S, TERZIOĞLU BEBITOĞLU B, YILMAZ AKYÜZ E, DOKUYUCU A, ERDEM Ş: Effect of calcium $\beta$-hydroxy- $\beta$-methylbutyrate (CaHMB), vitamin $\mathrm{D}$, and protein supplementation on postoperative immobilization in malnourished older adult patients with hip fracture: a randomized controlled study. Nutr Clin Pract 31: 829-835, 2016.

ELEY HL, RUSSELL ST, TISDALE MJ: Attenuation of depression of muscle protein synthesis induced by lipopolysaccharide, tumor necrosis factor, and angiotensin II by beta-hydroxy-beta-methylbutyrate. Am J Physiol Endocrinol Metab 295: E1409-E1416, 2008. 
GOMES-MARCONDES MCC, TISDALE MJ: Induction of protein catabolism and the ubiquitin-proteasome pathway by mild oxidative stress. Cancer Lett 180: 69-74, 2002.

HAO Y, JACKSON JR, WANG Y, EDENS N, PEREIRA SL, ALWAYS SE: $\beta$-Hydroxy- $\beta$-methylbutyrate reduces myonuclear apoptosis during recovery from hind limb suspension-induced muscle fiber atrophy in aged rats. Am J Physiol Regul Integr Comp Physiol 301: R701-R715, 2011.

HIGGINS GM, ANDERSON RM: Experimental pathology of the liver. I. Restoration of liver of white rat following partial surgical removal. Arch Pathol 12: 186-202, 1931.

HOLECEK M, SPRONGL L, TILSER I: Metabolism of branched-chain amino acids in starved rats: the role of hepatic tissue. Physiol Res 50: 25-33, 2001.

HOLECEK M, MUTHNY T, KOVARIK M, SISPERA L: Effect of beta-hydroxy-beta-methylbutyrate (HMB) on protein metabolism in whole body and in selected tissues. Food Chem Toxicol 47: 255-259, 2009.

HOLECEK M: Three targets of branched-chain amino acid supplementation in the treatment of liver disease. Nutrition 26: 482-490, 2010.

HOLECEK M, KOVARIK M: Alterations in protein metabolism and amino acid concentrations in rats fed by a highprotein (casein-enriched) diet - effect of starvation. Food Chem Toxicol 49: 3336-3342, 2011.

HOLECEK M, KANDAR R, SISPERA L, KOVARIK M: Acute hyperammonemia activates branched-chain amino acid catabolism and decreases their extracellular concentrations: different sensitivity of red and white muscle. Amino Acids 40: 575-584, 2011.

HOLEČEK M: Beta-hydroxy-beta-methylbutyrate supplementation and skeletal muscle in healthy and muscle-wasting conditions. J Cachexia Sarcopenia Muscle 8: 529-541, 2017.

HOLECEK M, VODENICAROVOVA M, SIMAN P: Acute effects of phenylbutyrate on glutamine, branched-chain amino acid and protein metabolism in skeletal muscles of rats. Int J Exp Pathol 98: 127-133, 2017.

HOLEČEK M, MIČUDA S: Amino acid concentrations and protein metabolism of two types of rat skeletal muscle in postprandial state and after brief starvation. Physiol Res 66: 959-967, 2017.

KADLCIKOVA J, HOLECEK M, SAFRANEK R, TILSER I, KESSLER BM: Effects of proteasome inhibitors MG132, ZL3VS and AdaAhx3L3VS on protein metabolism in septic rats. Int J Exp Pathol 85: 365-371, 2004.

KIMBALL SR, JEFFERSON LS: Regulation of protein synthesis by branched-chain amino acids. Curr Opin Clin Nutr Metab Care 4: 39-43, 2001.

KOVARIK M, MUTHNY T, SISPERA L, HOLECEK M: Effects of $\beta$-hydroxy- $\beta$-methylbutyrate treatment in different types of skeletal muscle of intact and septic rats. $J$ Physiol Biochem 66: 311-319, 2010.

LOWRY OH, ROSEBROUGH NJ, FARR AL, RANDALL RJ: Protein measurement with the Folin phenol reagent. J Biol Chem 193: 265-275, 1951.

NISSEN S, SHARP RL, PANTON L, VUKOVICH M, TRAPPE S, FULLER JC: beta-hydroxy-beta-methylbutyrate (HMB) supplementation in humans is safe and may decrease cardiovascular risk factors. $J$ Nutr 130: 1937-1945, 2000.

NISSEN SL, ABUMRAD NN: Nutritional role of the leucine metabolite $\beta$-hydroxy- $\beta$-methylbutyrate (HMB). J Nutr Biochem 8: 300-311, 1997.

OLVEIRA G, OLVEIRA C, DOÑA E, PALENQUE FJ, PORRAS N, DORADO A, GODOY AM, RUBIOMARTÍNEZ E, ROJO-MARTÍNEZ G, MARTÍN-VALERO R: Oral supplement enriched in HMB combined with pulmonary rehabilitation improves body composition and health related quality of life in patients with bronchiectasis (Prospective, Randomised Study). Clin Nutr 35: 1015-2102, 2016.

PORTAL S, ZADIK Z, RABINOWITZ J, PILZ-BURSTEIN R, ADLER-PORTAL D, MECKEL Y, COOPER DM, ELIAKIM A, NEMET D: The effect of HMB supplementation on body composition, fitness, hormonal and inflammatory mediators in elite adolescent volleyball players: a prospective randomized, double-blind, placebo-controlled study. Eur J Appl Physiol 111: 2261-2269, 2011.

RATHMACHER JA, NISSEN S, PANTON L, CLARK RH, EUBANKS MAY P, BARBER AE, D'OLIMPIO J, ABUMRAD NN: Supplementation with a combination of beta-hydroxy-beta-methylbutyrate (HMB), arginine, and glutamine is safe and could improve hematological parameters. JPEN J Parenter Enteral Nutr 28: 65-75, 2004. 
SMITH HJ, MUKERJI P, TISDALE MJ: Attenuation of proteasome-induced proteolysis in skeletal muscle by \{beta\}hydroxy-\{beta\}-methylbutyrate in cancer-induced muscle loss. Cancer Res 65: 277-283, 2005.

WANG TJ, LARSON MG, VASAN RS, CHENG S, RHEE EP, MCCABE E, LEWIS GD, FOX CS, JACQUES PF, FERNANDEZ C, O'DONNELL CJ, CARR SA, MOOTHA VK, FLOREZ JC, SOUZA A, MELANDER O, CLISH CB, GERSZTEN RE: Metabolite profiles and the risk of developing diabetes. Nat Med 17: 448-453, 2011.

YONAMINE CY, TEIXEIRA SS, CAMPELLO RS, GERLINGER-ROMERO F, RODRIGUES CF, GUIMARÃESFERREIRA L, MACHADO UF, NUNES MT: Beta hydroxy beta methylbutyrate supplementation impairs peripheral insulin sensitivity in healthy sedentary Wistar rats. Acta Physiol (Oxf) 212: 62-74, 2014.

ZHOU Y, XU JC, JIA YF, XU CS: Role of death receptors in the regulation of hepatocyte proliferation and apoptosis during rat liver regeneration. Genet Mol Res 14: 14066-14075, 2015. 